\title{
Nutrition and home-economics programme in Egyptian villages
}

\author{
By Mary A. Ross, FAO Home Economist under the Expanded Technical Assistance \\ Program, FAO Sindibis Project, Garden City, Cairo, Egypt
}

In 1953 the Government of Egypt and FAO jointly undertook a demonstration project in agriculture, rural industries, nutrition and home economics, the object of which is to improve the standard of living of the Egyptian village population. The sponsoring ministry for the Government was the Ministry of Agriculture. Five villages in the Nile Delta about $45 \mathrm{~km}$ north-west of Cairo were selected for the demonstration, which was designated the 'Sindibis Project' from the name of the district concerned. The villages are typical Egyptian villages with flat-roofed mud houses closely packed together and surrounded by fertile fields. The people farm for themselves, work for the larger land holders, or are small tradesmen or craftsmen. There is no centre near enough to provide industrial employment.

I was appointed by FAO in February 1954 to help in developing the nutritional and home-economics aspects of the project. Previously I had been Assistant Director, Nutrition Service, Community Service Society of New York and, more recently, Nutrition Consultant, Department of Health and Welfare, Maine, USA. The other two members of the FAO team were an agriculturist and an expert on rural industries.

The same five villages in the Sindibis area had served from 1948 to I 95 I as the locale of a study undertaken by the International Health Division of the Rockefeller Foundation, the purpose of which was 'to define the health and sanitary problem, to develop a program for improving rural health and sanitation, and to determine the effectiveness of these measures'.

The villages lie within the larger Calioub area in which WHO is assisting the Government of Egypt in another project known as the 'Calioub Demonstration and Training Program'. This is planned as a long-term demonstration of decentralized administration of welfare services, including health, agriculture, social affairs and education. The area includes a population of 200,000 living in forty-three towns and villages. The FAO team was invited to act in a consultant capacity in the more extensive Calioub project while continuing demonstration work in the Sindibis villages.

The programme now developing in the area is a co-operative enterprise in which the Ministries of Health, Agriculture, Social Affairs and Education, as well as WHO and FAO, are participating. I shall refer in this paper mainly to its nutritional and home-economics aspects, but emphasize the fact that the many problems of village life must be attacked simultaneously through co-ordinated efforts if progress is to be achieved.

All my work has been done in association with Egyptian colleagues who have accompanied me on visits to villages and taken part in the surveys and demonstrations, as well as acting as interpreters. The training of local people is part of this, 
as of ETAP projects in general, and I hope that the experience gained by my friendly and conscientious colleagues will be of value both to themselves and to their country.

A considerable number of nutritional investigations has been made in Egypt. Some of these have been concerned with broad problems of nutrition and measures to solve them, some with pellagra, a disease still found in Egypt, and others with parasitism and malnutrition and how they interact to impair the health of the population. Our work, however, has not followed these lines. We began by investigating foods used, methods of preparation, eating habits, child-feeding practices, household equipment and family life in order to find simple, inexpensive and acceptable steps that might be taken to improve the diets and living habits of the people. With the help of two young Egyptian women, a comprehensive study of twenty-three families in one village (Aghour Soughra) was undertaken as a basis for planning practical programmes in nutrition and home-economics education.

When I am asked 'How do you get into the homes?', I feel like replying 'The problem is how to get out' for the Egyptian fellaheen are very friendly, hospitable people. Visits were first paid to the omda or mayor, the leading sheikhs, schoolteachers and wealthy landowners, so that our aims would not be misinterpreted. During these visits we drank tea and explained our work, stressing our special interest in women and children and in the homes, and leading our host to talk about the problems of his people as he saw them. We did not, however, visit families together with male members of the FAO team, since this would be contrary to local custom.

Food habits have been observed and recorded for over a year but no quantitative food-intake studies have been undertaken. The staple food of villages in the Delta is a maize bread which has the appearance of a thin pancake about 14 in. in diameter. White-maize flour (about $96 \%$ extraction), to which $3 \%$ of fenugreek is added, is ground at the local mill and baked every 7-ro days. On the six feast days of the year wheat is purchased by all who can afford it, to make a special bread. A few wealthy families use wheat daily, and others mix varying amounts of wheat with the maize. In poorer homes adults and adolescents consume from I to $I \cdot 5 \mathrm{~kg}$ of this maize bread daily with some skim-milk cheese, mish (see below), molasses, leafy vegetables or doqqa (salt pounded with hot red pepper, cumin and other spices). Bread also serves as fork and spoon on the occasions when a meat dish, eggs or beans are added to the diet.

Families who possess a gamoosa (the big dark grey buffalo of Egypt) usually make butter daily, churning the whole milk in goatskin bags and selling butter for cash. They make a fresh white cheese from the buttermilk, using a piece of calf's stomach as a starter.

Families without a gamoosa purchase small amounts of cheese and mish. Mish is cheese aged with a mixture of buttermilk, salt, cottonseed cake and red pepper. The method of making this product is worth a brief description. The mixture is put into a clay jug holding about 4 gal., the neck of the jar is closed with a piece of leefah or palm fibre and the jug is placed in the sunniest corner of the roof for 
6-12 months. The mish is then a thin paste of greenish gray to creamy colour tasting like a very strong Roquefort to which red pepper has been added.

The gamoosa is probably the greatest single asset in the economy of village families. It provides the chief source of animal protein in the diet, fuel for cooking and power to run the irrigation pump and to plough the land, as well as being a source of income when butter or whole milk is sold. It shares the family home along with the donkey, goat, sheep, chickens and rabbits.

Eggs are usually sold or bartered to obtain sugar, tea, soap or vegetables. They are occasionally eaten by the men and older boys, but since they are considered to cause 'liver disease' they are generally avoided.

Meat is eaten once or twice a week by the more prosperous, but by poorer families only once or twice a month or only on the six feast days of the year. Camel and gamoos a meat are the kinds of meat most commonly eaten; sheep and goats are usually kept for feasts. As in all other Moslem countries, pork is never used. Many rabbits, chickens and ducks are kept, but these are sold in the market and are eaten by the family only on special occasions.

The shortage of fuel is a problem to all villagers, but for families without a gamoosa the problem is acute. Little girls belonging to these families are to be seen in the streets and fields gathering up dung to take home for gilla or fuel cakes. This scarcity of fuel is, I believe, one of the reasons for the very limited use of broad beans which could supplement the maize proteins in the village diet. In Cairo, the ful medamis or stewed dried broad beans are standard breakfast fare, but these are usually purchased already cooked since they require $\mathrm{I} 2 \mathrm{~h}$ of simmering to make them tender. Scarcity of fuel limits cooking to one hot meal in the evening and often to one hot meal every 2 or 3 days.

During the cooler months leafy vegetables, both wild and cultivated, are eaten in quantity by everyone. In the spring the leaves and tender green seeds of broad beans and chick-peas are a special delicacy. Potatoes, sweet potatoes, colcasia, marrow, cabbage and other vegetables are eaten in season. Tomatoes are plentiful the year round, but are chiefly used for cooking with meat. Mulberries and guavas growing in the villages are eaten by the children and a few oranges and mandarins may be bought for them by their parents. Fresh dates may be eaten in the fall. Fruits do not, however, form a regular part of the diet.

The excessive use of tea and sugar has been reported by many workers and it is probably true among men who earn regular cash. Many women expressed regret that they could not buy tea regularly for their husbands. On the first visit of a stranger to any home a child is given a half piastre and sent to the store to buy a tiny paper of tea, which is boiled with much sugar. After the first visit we were sometimes given helba-an infusion of fenugreek and sugar that is considered the drink of women, especially during pregnancy and lactation. The seed, which contains $26 \%$ protein, is eaten after the liquor is drunk and probably makes some contribution to the diet. The growing popularity of factory-made soft drinks, on which the villagers are all too ready to spend their scanty means, is alarming.

During the Ist year of our work, all teaching was done in the homes. Neighbours 
would always gather to observe, listen and join in the conversation. We soon learned to limit our suggestions to simple changes that could be easily understood and accepted by the group and could be demonstrated on the spot with materials and equipment available to the family. The simple economy of the home, the 'barter' value of eggs and chickens, the scarcity of fuel and the difficulty of carrying water must all be considered and understood in developing an educational programme. These are among the factors with which the home economist must learn to deal.

Cooking facilities in the homes are simple in the extreme. They may consist of a three-brick stove, a clay brazier in which maize cobs are burned, the huge oven for bread that also serves as sleeping space in winter, or, occasionally, an old primus stove. Equipment includes one or more tinned copper pots, clay bowls and jugs of various sizes, a large reed basket for storing bread; a flour sifter, a brass mortar and pestle and a few tin cans with twisted-wire handles.

The lack of any facilities for storing food or utensils, and the absence of established arrangements for meals, are constant sources of discouragement to the home economist. On the flat roof of the house one finds ears of maize in clay domes along with jars of mish and pickles; sugar, salt and spices are stored in the oven or the sleeping room, along with uncovered reed baskets holding 7-10 days' supply of bread.

Scarcity of fuel, lack of clean water in adequate amounts, absence of storage space protected from flies and dust, and the custom of preparing food on the mud floor all create problems of food contamination that are hard to solve. The incidence of intestinal infection is high. The difficulty of preparing foods that are safe for the weanling child is recognized and is reflected in the practice of nursing babies as long as possible, often into the 3 rd year. Dehydration often occurs as the mother's milk supply fails, for the women fear to give the child any supplementary food or water. Rickets is common up to 2 years of age; it may be related to the practice of placing babies in the windowless room (oven), and covering them completely when they are outside.

The heavy responsibilities of the woman and the arduous labour she performs make it desirable to simplify rather than complicate her daily life. Water must be carried, butter churned and cheese made every day. Maize is removed from the cob, taken to the mill, ground and sifted by hand, and bread baked every 7-10 days. This is an enormous task that requires three women to complete. The woman is also responsible for the chickens, goat and sheep. Many make a weekly trip to market, often walking $20 \mathrm{~km}$ to sell a few chickens, a dozen eggs, or a rabbit. Others make more frequent trips to sell articles to selected customers in another village. At the appropriate season, maize and cotton stalks are brought from the fields and prepared and carried to the roof in backbreaking loads. The woman makes many visits each day to the roof, going up and down on a mud staircase or a ladder to get fuel and food. In the summer the cooking is done there. During cotton planting and harvest and other seasons when extra labour is required, she works beside her husband and children in the fields. She sometimes turns the heavy tambour (the ancient 
screw of Archimedes) that irrigates the land, though this is considered 'man's work'.

During our survey of families in the villages of Aghour Soughra we had ample evidence that literacy is not an index of intelligence, for these village women, all of whom are illiterate, were able independently to express their needs and desires, which included help with child care and feeding, medical services, and schools for girls as well as boys.

Because of the interest of women in weaning problems, the educational programme began with the feeding of children in the $\mathrm{I}-5$ year old group. Mothers were shown how to dilute and boil gamoosa milk and how to prepare UNICEF milk powder supplied by the health centre. Subsequently, a 4 gal. oil can was adapted as a sterilizer and storage unit that keeps bottles of 'formula' milk and jars of food safe for a $24 \mathrm{~h}$ period.

We have co-operated in the animal husbandry work of the FAO group, helping the women to raise more baby chicks and rabbits and provide a ration for laying hens. A small co-operative is being formed in one of the villages through which a cream separator and churn will be purchased, thereby eliminating the time-consuming work of churning whole milk in goatskin bags.

In one village, experiments with maize bread were carried out in the homes. Weighed amounts of various local beans, soya beans and cottonseed flour were added to the maize and fenugreek before parching and grinding at the mill. It was possible in this way to achieve a bread containing $22 \%$ more protein, and no doubt a more satisfactory combination of amino-acids, without the use of additional fuel. The resulting bread was satisfactory and acceptable to the villagers, except that they did not like the yellow colour introduced by the addition of cottonseed flour. Unfortunately, beans are more expensive than maize and not always available to village families.

Alertness on the part of the home economists and the receptiveness of the people have led to the demonstration of several home improvements. These include an improved mud-brick stove which conserves fuel, eliminates smoke and the risk of fires, and gives the cook a working surface of comfortable height; porous clay jars with double walls and fitted covers which keep food cool by evaporation; palmstalk cupboards and shelves, a child's cot and other simple furniture which contribute to convenience and comfort in the homes. Because of the scarcity of soap and water, we are now trying to develop improved laundry methods.

The home economists have selected a small group of teen-age girls in each village to act as their assistants and to receive special training, this being part of a plan to develop an extension service for women. In addition, nurses, midwives, female schoolteachers and other village workers in the Calioub Project receive practical training in nutrition and home economics. Young physicians about to enter service in government health centres are given simple instruction in applied nutrition.

The kind of co-operation between workers in different fields which is now taking shape is needed in village work of this nature. Disease caused by unsafe handling 
of food in the home cannot be successfully controlled by the health centre. Home economics and nutrition programmes cannot proceed smoothly when workers are besieged with requests for medical care. Diets cannot be greatly improved until agriculture and rural industry provide more income for families and until farmers are taught to produce for home use foods which are good supplementary sources of protein and other nutrients. Programmes in village improvement cannot forge ahead until illiteracy among adults is abolished and schools are built to accommodate a larger proportion of the village children.

Our first interest-the care and feeding of the young child-remains our major interest. It is also one of the primary interests of the village women. We believe that by demonstrating satisfactory methods of feeding young children, including the preparation and storage of foods, the use of simple but improved home equipment, and habits of living that protect the health of the young child, we can help village people towards better ways of life.

The studies we have made of living conditions, and some of the trials and demonstrations described in this paper, should be of value in guiding work along similar lines on a wider scale elsewhere in Egypt. This in fact is the main purpose of the project. The extent of the need and of the task to be accomplished is evident.

A picture of Egyptian village life and its problems in greater detail than the brief sketch provided by this paper will be found in articles by Ammar (1954), Lane (1835), Ayrout (1928) and Weir, Farag Rizk Hassan, Salah-el-Din Mohammed Attia \& Mohammed Abdel Kader (1952).

\section{REFERENCES}

Ammar, H. (1954). Growing up in an Egyptian Village. London: Routledge and Kegan Powell. Ayrout, F. (1928). The Fellaheen. Cairo: Schindler Press.

Lane, E. W. (1835). The Manners and Customs of the Modern Egyptians. (Everyman's Library edition, reprinted I954). London: J. M. Dent and Sons.

Weir, M., Farag Rizk Hassan, Salah-el-Din Mohammed Attia \& Mohammed Abdel Kader (1952). F. Egypt. publ. Hlth Ass. 27, 55 .

\section{Nutrition work in Burma past and present}

\section{By S. PostMus, Senior WHO Officer, Nutrition Project, Burma, Rangoon}

Though the number of nutrition workers in Burma has been very limited, various kinds of nutrition work have been carried out.

Dr U Maung Gale, Public Health Officer, later Director of Health Services, carried out nutritional and dietary surveys in seven areas between 1939 and I94I with the assistance of trained volunteers well known in the areas surveyed. His work (U Maung Gale, 1948) was published in 1948 by the Government Printing Office in Rangoon and may be summarized as follows:

The calorie and total-protein intake was not always sufficient and the animal protein did not always reach Swaminathan's ( 1938 ) standard of at least $25 \%$ of the 